\title{
THE INFLUENCE OF URBANISATION ON AQUATIC MOLLUSC FAUNA: THE KRZNA RIVER (EAST POLAND)
}

\author{
EWA JURKIEWICZ-KARNKOWSKA
}

\begin{abstract}
Department of Health Sciences, Faculty of Natural Sciences, Siedlce University of Natural Sciences and Humanities, B. Prusa 12, 08-110 Siedlce, Poland (e-mail: ewa.jurkiewicz-karnkowska@uph.edu.pl)

ABSTRACT: The mollusc fauna of a medium-sized lowland river Krzna, which is almost entirely regulated and affected by urbanisation, was surveyed. The aim of the study was to determine if negative effects of urbanisation were evident in mollusc communities: their species richness, diversity and abundance, as well as composition and dominance patterns. Thirty one living mollusc species and empty shells of another two species were recorded. The simplification of the dominance pattern observed especially within and below Łuków and within Międzyrzec Podlaski may point to a negative effect of urbanisation. A decrease in species richness and diversity in response to urbanisation was recorded within Międzyrzec Podlaski, as well as below Łuków and Biała Podlaska. The mean abundance showed an increase in two urban and two downstream stretches. The relatively ambiguous response of malacocoenoses to urbanisation may result from the elimination of sensitive mollusc species by stressors associated with regulation of the river and release of untreated or insufficiently treated sewage in the past decades. Both the regulation of the river and urbanisation may have contributed to the negative effects on the malacocoenoses, but separation of the influence of these two anthropogenic stressors may be very difficult.
\end{abstract}

KEY WORDS: mollusc assemblages, diversity, urban river

\section{INTRODUCTION}

Urbanisation is among the major causes of stream and river impairment (e.g. PAUL \& MEYER 2001 and references therein, MEYER et al. 2005). Disadvantage of urbanisation include a decrease in imperviousness of the catchment to precipitation and an increase in surface runoff. Imperviousness is considered to be a good predictor of urbanisation and its effects on streams and rivers (e.g. KLEIN 1979, BOOTH \& JACKSON 1997). In consequence of increased surface runoff bankfull and flood discharges increase. Higher discharges contribute to channel enlargement due to erosion. Higher in-stream velocities cause changes in the sediment composition with increased coarse sand fractions. Removal of riparian vegetation causes unfavourable hydrological, physical (temperature) and chemical changes.

Urban areas strongly affect chemical characteristics of streams and rivers due to point sources (wastewater treatment plants, storm water drainage) and non-point sources - runoff. Generally, effluents from wastewater treatment plants and storm water drainage cause an increase in almost all chemical components of water in urban streams and rivers, including nutrients, calcium, sodium, potassium, magnesium and chloride ions, oxygen demand, conductivity, suspended solids, ammonium, hydrocarbons, metals, pharmaceuticals and personal care products (PAUL \& MEYER 2001 and literature therein, KAUSHAL \& BELT 2012, GILLIS et al. 2017 and literature therein). Moreover, leaking sewer systems and failing septic tanks are still considerable contributors of pollutants to urban waters (e.g. FAULKNER et al. 2000). The runoff from urban areas provides large amounts of nutrients, sodium and chloride ions, metals, pesticides, polychlorinated biphenyls (PCBs) and petroleum-based aliphatic hydrocarbons to streams and rivers (e.g. FOSTER et al. 2000). Numerous changes in stream ecosystems resulting from catchment urbanisation have been collectively termed the urban stream syndrome (MEYER et al. 2005, WALSH et al. 2005). 
Negative effects of urbanisation on macrobenthic invertebrates are associated with increased water turbidity, instability of bed sediments, frequent floods, reduced refugial space due to sedimentation, water pollution, sediment contamination and toxicity, riparian deforestation (e.g. PAUL \& MEYER 2001 and references therein, WENGER et al. 2009). Studies of the consequences of urban land use on freshwater invertebrates showed a decreased diversity and increased abundance in response to inorganic and organic nutrients (e.g. PAUL \& MEYER 2001, RoY et al. 2003, CUFFNEY et al. 2005). Higher abundances result from an increase in relative abundance of pollution-tolerant taxa including some gastropods (e.g. PRATT et al. 1981, THORNE et al. 2000, MOORE \& PALMER 2005). Toxins and siltation cause decrease in both diversity and abundance (e.g. PAUL \& MEYER 2001 and references therein).

\section{STUDY AREA}

The Krzna River is the biggest left-bank tributary of the middle Bug River; it drains South Podlasie Lowlands $\left(51^{\circ} 57^{\prime}-52^{\circ} 08^{\prime} \mathrm{N}, 22^{\circ} 14^{\prime}-23^{\circ} 31^{\prime} \mathrm{E}\right)$. It is a medium-sized river $(120 \mathrm{~km})$, with the catchment area of $3,353 \mathrm{~km}^{2}$. It arises from two streams with source areas located in the Łukowskie Forests - Krzna Północna and Krzna Południowa, the last is regarded as the beginning of the river. The streams join in Międzyrzec Podlaski, to form the Krzna River which continues its eastward flow to the confluence with the Bug River. The mean long-term discharge (SSQ) near the Krzna River mouth is $12.6 \mathrm{~m}^{3} \mathrm{~s}^{-1}$ (REPORT 2015). The river has been regulated along most of its
Mollusc fauna of urban reaches of streams and rivers was relatively rarely investigated in Poland (e.g. WŁOSIK-BIEŃCZAK 1997, 2000, 2001 and literature therein) and not compared with stretches upstream and downstream of urban areas in order to assess impact of urbanisation on mollusc communities.

In this study I focused on molluscs of a medium-sized lowland river Krzna which is almost entirely regulated and affected by urbanisation. The aim was to determine if negative effects of urbanisation were evident in malacocoenoses in terms of their response to the total influence of towns without emphasis on specific parameters. Mollusc species richness, diversity and abundance, as well as composition and dominance pattern of malacocoenoses, were investigated in river stretches within three towns and compared with stretches located upstream and downstream of the urban areas.

course except short sections below its sources and before the mouth.

The valley is from $400 \mathrm{~m}$ to about $2 \mathrm{~km}$ wide, its area has been transformed (deforested and drained); at present it is used as meadows, pastures and arable fields. The Krzna River valley and its source area are covered by the Natura 2000 network (three Special Areas of Conservation - SACs: PLB060010, PLH060066, PLH060108), two Landscape Protection Areas (and one planned) and a fragment of the Landscape Park Podlaski Przełom Bugu. The area includes three nature reserves (Jata, Czapli Stóg and Kania).

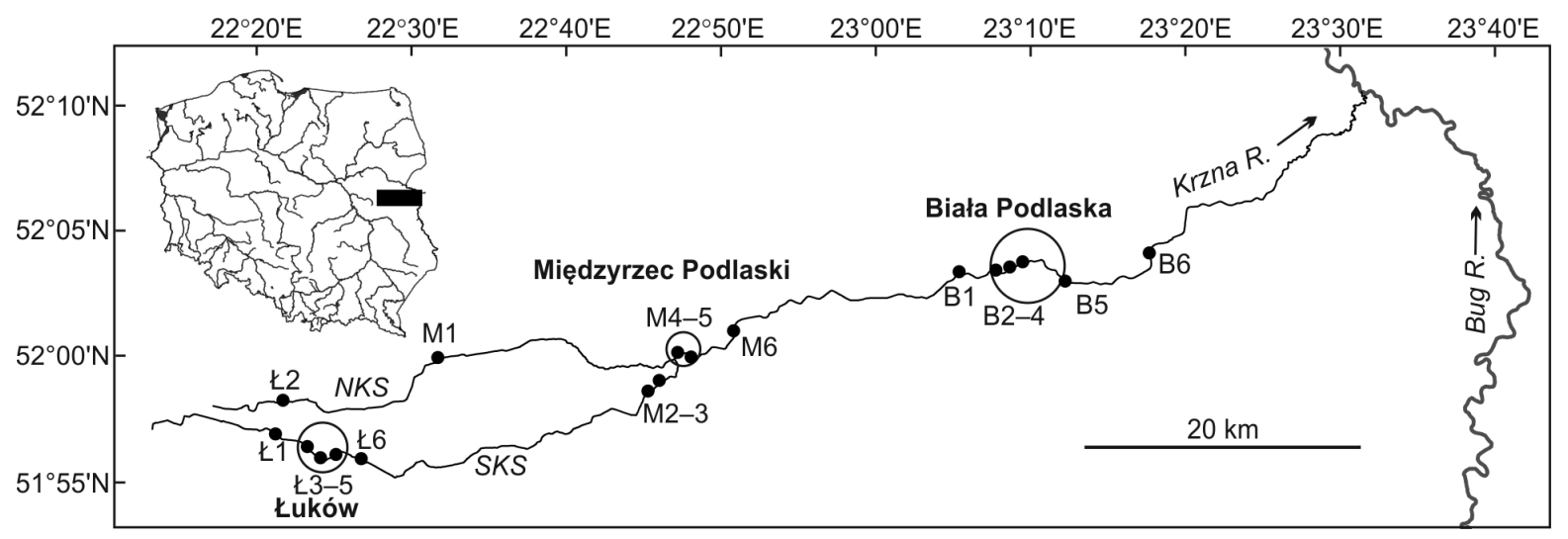

Fig 1. Study area and location of sites: black rectangle - study area, black points - collecting sites, circles - urban areas; NKS - North Krzna Stream (Krzna Północna), SKS - South Krzna Stream (Krzna Południowa). Sites located in the following river stretches: Ł1 and Ł2 upstream of Łuków (ŁR1), sites Ł3-5 in Łuków town (ŁU), site Ł6 downstream of Łuków (ŁR2), sites M1-3 upstream of Międzyrzec Podlaski (MR1), sites M4-5 in Międzyrzec Podlaski town (MU), site M6 downstream of Międzyrzec Podlaski (MR2), site B1 upstream of Biała Podlaska (BR1), sites B2-5 in Biała Podlaska town (BU) and site B6 downstream of Biała Podlaska (BR2)

ŁR1, ŁU, ŁR2 - upstream of Łuków, Łuków town, downstream of Łuków; MR1, MU, MR2 - upstream of Międzyrzec Podlaski, Międzyrzec Podlaski town, downstream of Międzyrzec Podlaski; BR1, BU, BR2 - upstream of Biała Podlaska, Biała Podlaska town, downstream of Biała Podlaska 
The Krzna River catchment is affected by both chemical and physical consequences of urbanisation. The towns are relatively small, the largest being Biała Podlaska (population of ca. 60 thousand), but they may considerably affect this medium-sized river, especially within its upper and middle course. The Krzna receives effluents from three municipal wastewater treatment plants, big meat processing plant in Łuków, another two in the vicinity of Międzyrzec Podlaski and one located a few kilometers below Biała Podlaska (REPORT 2016). The sewage system within the rural area of the Krzna River catchment is not sufficient, resulting in an increased threat of river contamination associated with on-site septic systems; some small local sewage treatment plants and many septic tanks function there. The surface runoff from impervious urban areas and agricultural areas is regarded as a very important non-point source of the river pollution, but its contribution has not been assessed (REPORT 2015). Several years ago the water quality was mostly medium (PROGRAM 2012), mainly due to increased phosphorus concentrations. At pres-

\section{METHODS}

Molluscs were sampled during summer low flows, at the beginning of July in 2017-2018 using a hand net with a working side of $25 \mathrm{~cm}$, mesh size of 0.5 $\mathrm{mm}$ and handle length of $2 \mathrm{~m}$. Individual sites were investigated during one sampling event usually taking 1-3 samples. Samples were collected from ca. $1 \mathrm{~m}^{2}$ of the bottom area covering all microhabitats visually detected, the depth did not exceed $1.5 \mathrm{~m}$. They were washed on a sieve of $0.5 \mathrm{~mm}$ mesh and preserved with $75 \%$ ethyl alcohol. In the laboratory molluscs were sorted, counted and identified using the key of PIECHOCKI \& WAWRZYNIAK-WYDROWSKA (2016).

At each sampling site the river width was measured directly in the field with measuring tape, the depth was assessed with calibrated pole. The current velocity was measured using a float and stopwatch. The results were expressed as categorical values, i.e. river width: $<2 \mathrm{~m}, 2-<5 \mathrm{~m}, 5-<10 \mathrm{~m}, 10-<15 \mathrm{~m}$, $\geq 15 \mathrm{~m}$; river depth: $<0.5 \mathrm{~m}, 0.5-<1 \mathrm{~m}, \geq 1 \mathrm{~m}$; current velocity: $<<0.1 \mathrm{~m} / \mathrm{s}$ (i.e. close to 0 ), $<0.1 \mathrm{~m} / \mathrm{s}$, $0.1-<0.2 \mathrm{~m} / \mathrm{s}, 0.2-0.3 \mathrm{~m} / \mathrm{s}$.

\section{RESULTS}

\section{COMPOSITION AND STRUCTURE OF MALACOCOENOSES}

Thirty one living mollusc species and empty shells of another two species were recorded from the ent it is at least not worse, especially because of activities concerning effectiveness of wastewater treatment (e.g. http://bwikwodkan.pl/). This tendency is confirmed by river potential determined based on biological components (REPORT 2015, 2016, 2017).

The study area included 18 sites: 2 within Krzna Północna, 7 within Krzna Południowa and 9 within Krzna. Nine of them were located in three urban areas (Łuków: Ł3, Ł4, Ł5, Międzyrzec Podlaski: M4, M5 and Biała Podlaska: B2, B3, B4, B5) and the others were distributed in rural areas upstream (6 sites: Ł1, Ł2, M1, M2, M3, B1) and downstream (3 sites: Ł6, M6, B6) of the towns (Fig. 1). The investigated river sections were characterised by relatively abundant macrophytes (except one site in Łuków devoid of macrophytes) and mostly sandy-muddy bottom, often with considerable detritus admixture (only at single sites muddy or sandy bottom was observed). The river width ranged from $<2 \mathrm{~m}$ to $>15 \mathrm{~m}$, the depth from $<0.5 \mathrm{~m}$ to $>1 \mathrm{~m}$, the current velocity varied from nearly 0 to $0.3 \mathrm{~m} / \mathrm{s}$. There was herbaceous buffer along the riversides at rural and some urban sites.

The sampling bias in the collection was tested with species accumulation curve and the abundance-based non-parametric estimators Chaol, Chao 2 and ACE. The dataset was considered complete if at least $90 \%$ of the number of species predicted with the estimators were found, and representative when over $70 \%$ of predicted number of species were recorded. The Shannon index $\left(\mathrm{H}^{\prime}\right)$ and true diversity $\left(\exp \left(\mathrm{H}^{\prime}\right)\right.$; JOST 2006) were calculated based on the mollusc abundance data. These calculations were carried out with EstimateS, v. 9 software (COLWELl 2013). The dominance patterns were estimated as the proportion of individual species within the total mollusc abundance. The Jaccard similarity coefficient (J; CHAO et al. 2005) was calculated for all pair-wise comparisons between the stretches located within the towns, as well as upstream and downstream of them.

The data on mollusc species richness, Shannon index $\left(\mathrm{H}^{\prime}\right)$, true diversity $\left(\exp \left(\mathrm{H}^{\prime}\right)\right)$ and abundance were compared between all the distinguished river stretches with nonparametric Kruskal-Wallis ANOVA rank test using STATISTICA 12.0 software (StatSoft).

study area (Table 1). The mollusc species list and the datasets for the urban stretches and rural stretches upstream of the towns can be regarded as complete ( $>90 \%$ of species richness estimated with ACE and Chao1, Table 2). The high values of Chao 2 resulted 
from the large proportion of species represented only by a single individual found in the sample (i.e. singletons). The dataset for rural stretches downstream of the towns was not complete owing to an exception- ally large number of singletons. Under such circumstances a greater sampling effort would be necessary. A similar species richness was observed at urban and rural sites (25 and 26 living species, respectively).

Table 1. Occurrence of molluscs within urban and rural stretches of the Krzna River; o - empty shells

\begin{tabular}{|c|c|c|c|}
\hline \multirow{2}{*}{ Species } & \multirow{2}{*}{ Urban sites } & \multicolumn{2}{|c|}{ Rural sites } \\
\hline & & Upstream of towns & Downstream of towns \\
\hline \multicolumn{4}{|l|}{ Prosobranchia } \\
\hline Bithynia tentaculata (Linnaeus, 1758) & + & + & + \\
\hline Valvata cristata O. F. Müller, 1774 & & + & \\
\hline V. piscinalis (O. F. Müller, 1774) & + & + & + \\
\hline Viviparus contectus (Millet, 1813) & + & + & \\
\hline \multicolumn{4}{|l|}{ Pulmonata } \\
\hline Acroloxus lacustris (Linnaeus, 1758) & + & + & + \\
\hline Lymnaea stagnalis (Linnaeus, 1758) & + & + & \\
\hline Radix ampla (Hartmann, 1821) & $\mathrm{o}$ & & + \\
\hline R. balthica (Linnaeus, 1758) & $\mathrm{o}$ & + & \\
\hline Stagnicola corvus (Gmelin, 1791) & + & + & \\
\hline S. palustris (O. F. Müller, 1774) & + & & \\
\hline Physa acuta Draparnaud, 1805 & + & & \\
\hline P. fontinalis (Linnaeus, 1758) & + & + & + \\
\hline Anisus calculiformis (Sandberger, 1875) & + & & \\
\hline A. leucostoma (Millet, 1813) & $\mathrm{o}$ & + & \\
\hline A. vortex (Linnaeus, 1758) & + & + & + \\
\hline Bathyomphalus contortus (Linnaeus, 1758) & + & + & \\
\hline Gyraulus albus (O. F. Müller, 1774) & + & + & + \\
\hline G. crista (Linnaeus, 1758) & + & & + \\
\hline Planorbarius corneus (Linnaeus, 1758) & + & + & + \\
\hline Planorbis planorbis (Linnaeus, 1758) & + & & + \\
\hline Segmentina nitida (O. F. Müller, 1774) & + & & \\
\hline \multicolumn{4}{|l|}{ Bivalvia } \\
\hline Anodonta anatina (Linnaeus, 1758) & + & & + \\
\hline Unio tumidus Philipsson, 1788 & + & & \\
\hline Musculium lacustre (O. F. Müller, 1774) & + & & + \\
\hline Pisidium amnicum (O. F. Müller, 1774) & $\mathrm{o}$ & & $\mathrm{o}$ \\
\hline P. casertanum (Poli, 1791) & + & + & \\
\hline P. henslowanum (Sheppard, 1823) & o & o & + \\
\hline P. milium Held, 1836 & & + & \\
\hline P. nitidum Jenyns, 1832 & + & & + \\
\hline P. pulchellum Jenyns, 1832 & & $\mathrm{o}$ & \\
\hline P. subtruncatum Malm, 1855 & + & + & + \\
\hline P. supinum A. Schmidt, 1851 & + & & + \\
\hline Sphaerium corneum (Linnaeus, 1758) & + & + & + \\
\hline Total number of species: $31+2$ empty shells & $25+5$ empty shells & $18+2$ empty shells & $17+1$ empty shell \\
\hline
\end{tabular}

Table 2. Comparison of numbers of species found within urban river stretches, rural stretches upstream and downstream of the towns and the entire study area with expected species richness calculated with non-parametric abundance-based estimators ACE, Chaol and Chao2; values in parentheses show percent of estimated richness comprised by a number of species found

\begin{tabular}{lcccc}
\hline \multicolumn{1}{c}{ River stretches } & Number of species found & ACE & Chao1 & Chao2 \\
\hline Upstream of the towns & 18 & $20.00(90.0 \%)$ & $19.49(92.4 \%)$ & $24.30(74.1 \%)$ \\
Urban & 25 & $25.82(96.8 \%)$ & $25.14(99.4 \%)$ & $56.06(44.2 \%)$ \\
Downstream of the towns & 17 & $24.47(69.5 \%)$ & $34.94(48.7 \%)$ & $41.20(41.3 \%)$ \\
\hline Total & 31 & $32.01(96.8 \%)$ & $31.25(99.2 \%)$ & $37.23(83.3 \%)$ \\
\hline
\end{tabular}




\begin{tabular}{l|c|c|c|c|c|c|c|c} 
ŁU & 0.37 & & & & & & & \\
ŁR2 & 0.20 & 0.29 & & & & & & \\
MR1 & 0.31 & 0.56 & 0.23 & & & & & \\
MU & 0.18 & 0.13 & 0.29 & 0.20 & & & & \\
MR2 & 0.38 & 0.37 & 0.40 & 0.42 & 0.29 & & & \\
BR1 & 0.27 & 0.44 & 0.36 & 0.50 & 0.25 & 0.67 & & \\
BU & 0.21 & 0.32 & 0.32 & 0.27 & 0.11 & 0.32 & 0.37 & \\
BR2 & 0.11 & 0.14 & 0.07 & 0.06 & 0.10 & 0.14 & 0.21 & 0.29 \\
& ŁR1 & ŁU & ŁR2 & MR1 & MU & MR2 & BR1 & BU
\end{tabular}

Fig. 2. Species similarity (Jaccard similarity coefficient, J) of malacofauna of the investigated river stretches. For abbreviations ŁR1, ŁU, ŁR2, MR1, MU, MR2, BR1, BU, BR2 see Fig. 1

Within the rural stretches similar numbers of species were noted upstream and downstream of the towns (18 and 17 living species, respectively). Twenty species were common for rural and urban habitats and eleven species were specific (i.e. found only in one group of river stretches - upstream, within or downstream of the towns). Stagnicola palustris, Physa acuta, Anisus calculiformis, Segmentina nitida and Unio tumidus were found only at urban sites, whereas Valvata cristata, Radix balthica, Anisus leucostoma, Pisidium milium, $R$. ampla and $P$. henslowanum were recorded exclusively at rural sites - the last two species were recorded downstream of the towns and the other four species upstream of the towns. The molluscs occurring within the study area were mostly ubiquitous species, tolerant to lower quality of water (especially lower oxygen concentration, higher concentrations of nitrogen and phosphorus, higher values of $\mathrm{BOD}_{5}$ and conductivity). Many of them are typically associated with macrophytes and slow-flowing waters. One alien species was found ( $P$. acuta); it was collected only in Łuków town (sites Ł4 and Ł5).

The mollusc communities showed a relatively low species similarity among the rural sites upstream of the towns, urban sites and rural sites downstream of the towns (J values $0.20-0.42$, Fig. 2). The malacocoenosis of the rural site downstream of Biała Podlaska showed the least similarity with the other sites within the study area.

Bithynia tentaculata and Valvata piscinalis were common in the entire study area and the three groups of river stretches: urban and rural upstream and downstream of the towns (they occurred in $50-80 \%$ of samples). Species which were found only in one sample strongly prevailed, they constituted $44 \%, 48 \%$ and $65 \%$ of all samples in the urban sites, rural sites upstream and downstream of the towns, respectively.

The dominance pattern of the mollusc communities varied widely among the investigated sites, but some differences among rural stretches upstream of the towns, urban stretches and rural stretches downstream of the towns could be noticed (Fig. 3). The malacocoenoses of the urban stretches within Łuków and Międzyrzec Podlaski where characterised by a strong dominance of $V$. piscinalis, whereas within Biała Podlaska the dominance pattern was characterised by a great proportion of species represented by one or two individuals, and only three species showed percentages from 8.3 to $16.7 \%$. From among

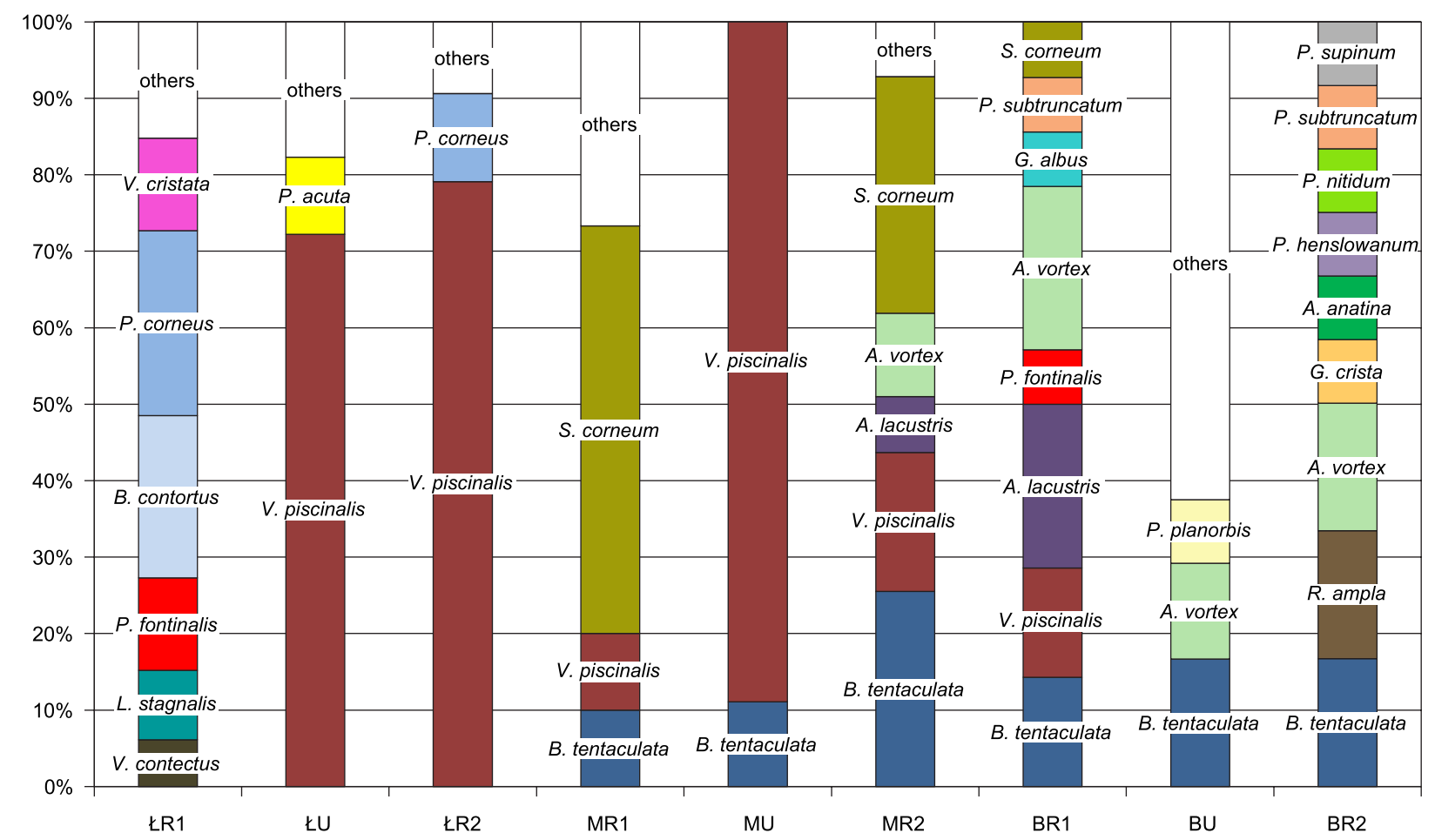

Fig. 3. Dominance patterns of mollusc communities within the river stretches. For abbreviations ŁR1, ŁU, ŁR2, MR1, MU, MR2, BR1, BU, BR2 see Fig. 1 
Table 3. Comparison of species richness, Shannon index $\left(\mathrm{H}^{\prime}\right)$, true diversity $\left(\exp \left(\mathrm{H}^{\prime}\right)\right)$ and abundance of molluscs in urban sites and rural sites upstream and downstream of the towns

\begin{tabular}{|c|c|c|c|c|}
\hline & $\begin{array}{c}\text { Rural sites } \\
\text { upstream of towns }\end{array}$ & $\begin{array}{l}\text { Urban } \\
\text { sites }\end{array}$ & $\begin{array}{c}\text { Rural sites downstream } \\
\text { of towns }\end{array}$ & $\begin{array}{c}\text { Values of } \\
\text { Kruskal-Wallis test }\end{array}$ \\
\hline Number of species & $\begin{array}{l}5.20 \pm 2.28 \\
\quad(3-8)\end{array}$ & $\begin{array}{l}6.56 \pm 3.64 \\
(1-12)\end{array}$ & $\begin{array}{l}8.00 \pm 1.15 \\
\quad(7-9)\end{array}$ & $\begin{array}{c}\mathrm{H}(2, \mathrm{~N}=18)=2.2123 \\
\mathrm{p}=0.3308\end{array}$ \\
\hline $\mathrm{H}^{\prime}$ & $\begin{array}{c}1.34 \pm 0.44 \\
(0.90-1.97)\end{array}$ & $\begin{array}{l}1.21 \pm 0.80 \\
(0-2.14)\end{array}$ & $\begin{array}{c}1.64 \pm 0.59 \\
(0.79-2.14)\end{array}$ & $\begin{array}{c}\mathrm{H}(2, \mathrm{~N}=18)=1.0240 \\
\mathrm{p}=0.5993\end{array}$ \\
\hline $\operatorname{Exp}\left(\mathrm{H}^{\prime}\right)$ & $\begin{array}{l}4.15 \pm 1.94 \\
(2.46-7.17)\end{array}$ & $\begin{array}{c}4.28 \pm 2.74 \\
(1.00-8.50)\end{array}$ & $\begin{array}{l}5.75 \pm 2.68 \\
(2.20-8.50)\end{array}$ & $\begin{array}{c}\mathrm{H}(2, \mathrm{~N}=18)=1.0240 \\
\mathrm{p}=0.5993\end{array}$ \\
\hline Abundance indiv. $/ \mathrm{m}^{2}$ & $\begin{array}{c}20.40 \pm 28.10 \\
(3-70)\end{array}$ & $\begin{array}{c}33.90 \pm 52.10 \\
(2-169)\end{array}$ & $\begin{array}{c}78.00 \pm 78.00 \\
(12-191)\end{array}$ & $\begin{array}{c}\mathrm{H}(2, \mathrm{~N}=18)=3.3691 \\
\mathrm{p}=0.1855\end{array}$ \\
\hline
\end{tabular}

the rural sites the dominance patterns upstream and downstream of Biała Podlaska were more complex then the others, the simplest dominance structure was found downstream of Łuków and upstream of Międzyrzec Podlaski.

\section{COMPARISON OF SPECIES RICHNESS, DIVERSITY AND ABUNDANCE IN URBAN AND RURAL RIVER SECTIONS}

The numbers of living species at individual sites ranged from 1 to 12 , the mean value was from 5.20 at upstream sites to 8.00 at downstream sites (Table 3). The species richness varied widely (Fig. 4), with the lowest value in Międzyrzec Podlaski and the highest in Biała Podlaska. A similar trend was found in the case of Shannon diversity index $\left(\mathrm{H}^{\prime}\right)$ and true diversity $\left(\exp \left(\mathrm{H}^{\prime}\right)\right)$ (Fig. 5). At individual sites $\mathrm{H}^{\prime}$ ranged from 0 to 2.14 and $\exp \left(\mathrm{H}^{\prime}\right)$ from 1.00 to 8.50 , whereas the mean $\mathrm{H}^{\prime}$ was 1.21 within towns to 1.64 in downstream stretches and the exp $\left(\mathrm{H}^{\prime}\right)$ values from 4.15 upstream of the towns to 5.75 downstream (Table 3).

The mollusc abundance at individual sites ranged from 2 to 191 indiv. $/ \mathrm{m}^{2}$ (Table 3). The mean values showed an increase in urban ( $€ U, B U)$ and downstream stretches (ŁR2, MR2) (Fig. 6). The malacocoenoses within Łuków and downstream of this town were the most abundant mainly due to the abundant occurrence of Valvata piscinalis.

The comparison of species richness, Shannon diversity index, true diversity and abundance of malacocoenoses among urban and rural sites upstream and downstream of the towns did not reveal any statistically significant differences (Table 3 ).

\section{DISCUSSION}

The Krzna River has a relatively rich malacofauna despite the regulation and the influence of urbanisation. The total number of species found during this study was smaller than in another big tributary of the Bug River - the Liwiec River - which has a fairly natural channel in the middle and lower sections and a natural valley (JURKIEWICZ-KARNKOWSKA 2016).
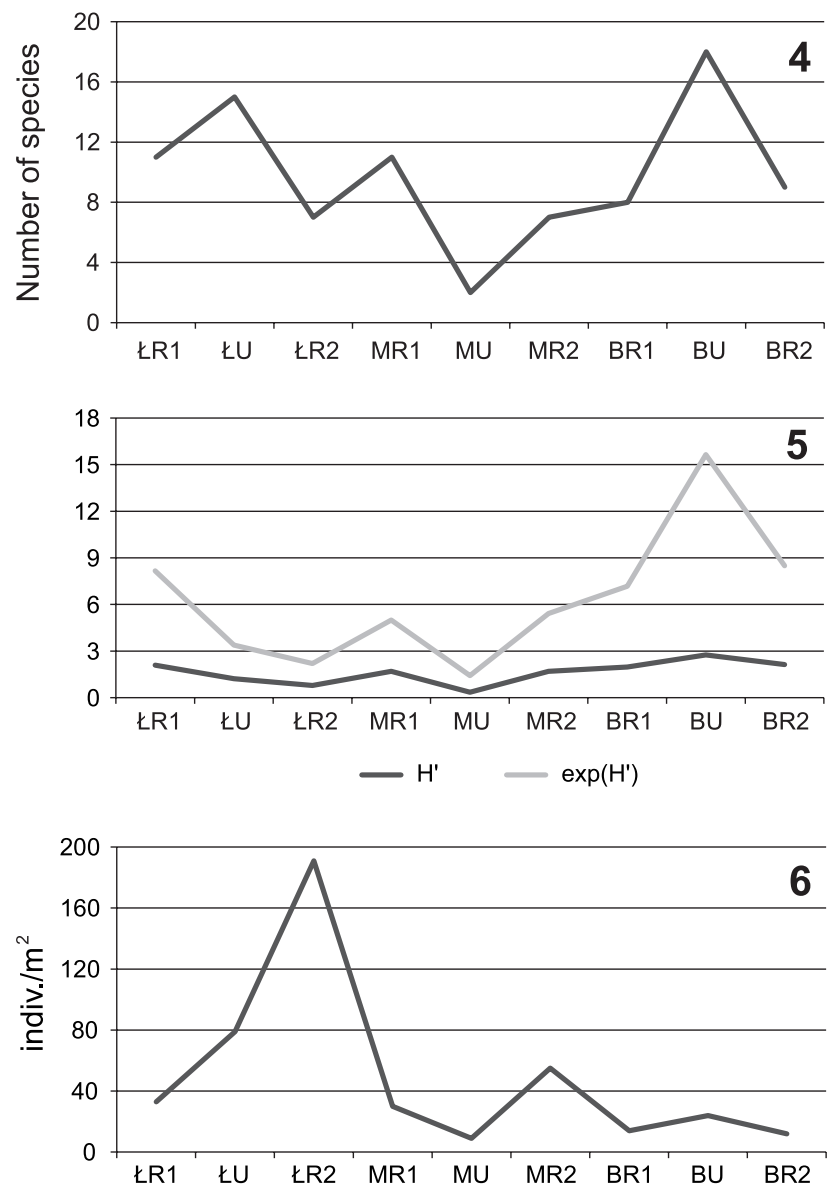

Figs 4-6. Pattern of changes in mollusc assemblages in consecutive river stretches: 4 - species richness, 5 Shannon index $\left(\mathrm{H}^{\prime}\right)$ and true diversity $\left(\exp \left(\mathrm{H}^{\prime}\right)\right), 6-$ abundance. For abbreviations ŁR1, ŁU, ŁR2, MR1, MU, MR2, BR1, BU, BR2 see Fig. 1

However, the mollusc species richness was similar to the numbers reported from some other Polish medium-sized rivers (e.g. PIECHOCKI 1981), some Lithuanian (PliŪRAITÉ \& KESMINAS 2004) and Czech rivers (e.g. BERAN 2013) of comparable size, as well as the Danube tributaries in Hungary (BóDIs et al. 2016). The species richness within the urban river sec- 
tions was comparable to the values reported from the Cybina River (WŁOsIK-BIEŃCZAK 1997), Bogdanka River in 1994, 1995, 1996 (WŁOSIK-BIEŃCZAK 2001) and higher than in the Junikowski Stream (WŁOsIKBIEŃCZAK 2000), all within Poznań city.

The Krzna River catchment is undoubtedly affected by urbanisation even though the towns are not large. There is evidence that even very low-density development can have negative effects on aquatic ecosystems (e.g. CUFFNEY et al. 2005, WENGER et al. 2009). Some negative changes in mollusc assemblages in response to urbanisation were observed, but they were not clear. A visible decrease in mollusc species richness, diversity and abundance was recorded within Międzyrzec Podlaski, as well as below Łuków and Biała Podlaska. The simplification of dominance pattern, especially within and below Łuków and within Międzyrzec Podlaski also point to the negative effect of urbanisation. The exceptionally poor malacofauna occurring in Międzyrzec Podlaski in spite of quite abundant macrophytes may reflect a bad environment quality resulting from considerable effluent load (STRATEGY 2015). There are more point sources of contamination within this stretch compared to the other urban ones (three larger wastewater treatment plants including two industrial and one municipal one). The Krzna Południowa stream in Łuków is affected by effluents from the municipal wastewater treatment plant and big meat processing plant, whereas the Krzna River in Biała Podlaska receives effluent from the municipal wastewater treatment plant, which is the only one totally modernised and at present the values of all chemical parameters of the treated sewage are below the norm (http://bwikwodkan.pl/).

There is evidence that non-point sources of pollution, i.e. surface runoff from urban areas, may provide more contaminants to rivers than point sources and their importance increases with an increase of the proportion of impervious surfaces (e.g. PAUL \& Meyer 2001 and references therein, MoOre \& PALMER 2005). The dispersed development in a considerable part of Biała Podlaska and the large green areas may reduce the runoff. This may be one of the main reasons for the richer and more diverse malacofauna in Biała Podlaska compared to the other two towns. An increase of impervious surface cover is considered to be a very important factor contributing to decrease in aquatic macroinvertebrate diversity (e.g. STEPENUCK et al. 2002).

\section{REFERENCES}

BERAN L. 2013. Freshwater molluscs of the Dyje (Thaya) River and its tributaries - the role of these water bodies in expansion of alien species and as a refuge for endan-
The relatively ambiguous response of malacocoenoses to urbanisation may result from the earlier elimination of sensitive mollusc species by stressors associated with the river's regulation which started in the 1930s, and release of untreated or insufficiently treated sewage in the past decades. The malacocoenoses were dominated by tolerant species of gastropods and a small bivalve Sphaerium corneum. Increases in relative abundance of pollution-tolerant taxa including some molluscs, especially gastropods, in response to water contamination were reported in some papers (e.g. WALSH et al. 2001, PAUL \& MeYer 2001, Roy et al. 2003, MOORE \& PALMER 2005). Bivalves, except S. corneum, formed a small proportion in the total mollusc abundance, at most of sites they constituted from zero to few percent, only within Biała Podlaska and downstream of this town their proportion was higher: 24 and $32 \%$, respectively, including the Unionidae found only there (ca. $8 \%$ in both river stretches). The Unionidae are regarded as sensitive to habitat alterations and poor water quality (GILLIS et al. 2017 and literature therein). The two species found in the Krzna River (Anodonta anatina and Unio tumidus) are relatively less sensitive unionids in Poland (e.g. PIECHOCKI \& WAWRZYNIAK-WYDROWSKA 2016). Another three species recorded during an earlier study in the Krzna River within Biała Podlaska: A. cygnea, U. pictorum and U. crassus (CYWKOWSKA 2009) were not found during this survey. Most representatives of Sphaeriidae also require good habitat quality (e.g. PIECHOCKI \& WAWRZYNIAK-WYDROWSKA 2016). Although high prevalence of bivalves in mollusc assemblages (ca. $78 \%$ of the abundance) was reported from another medium-sized tributary of the Bug River - the Liwiec River (JURKIEWICZ-KARNKOWSKA 2016), at the site below the outlet of a modern sewage treatment plant in Siedlce town, only P. nitidum was found with about 9\% relative abundance in the poor malacocoenosis occurring there. This confirms that even well treated sewage released to the river may considerably affect mollusc communities, especially bivalves.

Both the river's regulation and urbanisation may have resulted in changes in the composition and dominance patterns, as well as decline in species richness and diversity of the malacofauna inhabiting the Krzna River, but separation of the effects of these two anthropogenic stressors may prove very difficult.

gered gastropods and bivalves. Folia Malacologica 21: 143-160. https://doi.org/10.12657/folmal.021.018

BÓDIS E., TÓTH B., SOUSA R. 2016. Freshwater mollusc assemblages and habitat associations in the Danube River 
drainage, Hungary. Aquatic Conservation: Marine and Freshwater Ecosystems 26: 319-332. https://doi. org/10.1002/aqc.2585

BOOTH D. B., JACKSON C. R. 1997. Urbanization of aquatic systems: degradation thresholds, stormwater detection, and the limits of mitigation. Journal of the American Water Resources Association 33: 1077-1090. https:// doi.org/10.1111/j.1752-1688.1997.tb04126.x

CHAO A., CHAZDON R. L., COLWEll R. K., SHEN T.-J. 2005. A new statistical approach for assessing of similarity of species composition with incidence and abundance data. Ecology Letters 8: 148-159. https://doi. org/10.1111/j.1461-0248.2004.00707.x

COLWELl R. K. 2013. EstimateS: Statistical estimation of species richness and shared species from samples. Version 9. Available online at purl.oclc.org/estimates (accessed 20 October 2018).

CuffNey T. F., ZAPPIA H., COLES J. F. 2005. Effects of urbanization on benthic macroinvertebrate assemblages in contrasting environmental settings: Boston, Massachusetts; Birmingham, Alabama; and Salt Lake City, Utah. American Fisheries Society Symposium 47: 361-407.

CYWKOWSKA M. 2009. Różnorodność malakofauny rzeki Krzny w granicach miasta Biała Podlaska. M. Sc. Thesis, Akademia Podlaska, Siedlce.

FAUlKneR H., EDMONDS-Brown V., GREeN A. 2000. Problems of quality designation in diffusely populated urban streams - the case of Pymme's Brook, North London. Environmental Pollution 109: 91-107. https:// doi.org/10.1016/S0269-7491(99)00227-4

FOSTER G. D., ROBERTS E. C. JR, GRUESSNER B., VELINSKY D. J. 2000. Hydrogeochemistry and transport of organic contaminants in an urban watershed of Chesapeake Bay (USA). Applied Geochemistry 15: 901-916. https://doi. org/10.1016/S0883-2927(99)00107-9

Gillis P. L., MCINNIS R., SALERNO J., DE SOlla S. R., SERVOS M. R., LEONARD E. M. 2017. Freshwater mussels in an urban watershed: Impacts of anthropogenic inputs and habitat alterations on populations. Science of the Total Environment 574: 671-679. https://doi.org/10.1016/j. scitotenv.2016.09.110

JOsT L. 2006. Entropy and diversity. Oikos 113: 363-375. https://doi.org/10.1111/j.2006.0030-1299.14714.x

JURKIEWICZ-KARNKOWSKA E. 2016. Longitudinal pattern of mollusc assemblages within a medium-sized lowland river: Liwiec (East Poland). Folia Malacologica 24: 209-222. https://doi.org/10.12657/folmal.024.018

KAUSHAL S. S., BELT K. T. 2012. The urban watershed continuum: evolving spatial and temporal dimensions. Urban Ecosystems 15: 409-435. https://doi. org/10.1007/s11252-012-0226-7

KLEIN R. D. 1979. Urbanization and stream quality impairment. Water Resources Bulletin 15: 948-963. https:// doi.org/10.1111/j.1752-1688.1979.tb01074.x

Meyer J. L., Paul M. J., TAulbee W. K. 2005. Stream ecosystem function in urbanizing landscapes. Journal of the North American Benthological Society 24: 602-612. https://doi.org/10.1899/04-021.1

Moore A. A., PAlmer M. A. 2005. Invertebrate biodiversity in agricultural and urban headwater streams: implications for conservation and management. Ecological Applications 15: 1169-1177. https://doi. org/10.1890/04-1484

PAUl M. J., MEYER J. L. 2001. Streams in the urban landscape. Annual Review of Ecology, Evolution, and Systematics 32: 333-365. https://doi.org/10.1146/annurev.ecolsys.32.081501.114040

PIECHOCKI A. 1981. Współczesne i subfosylne mięczaki (Mollusca) Gór Świętokrzyskich. Acta Univ. Lodziensis, Łódź.

PIECHOCKI A., WAWRZYNIAK-WYdROWSKA B. 2016. Guide to freshwater and marine Mollusca of Poland. Bogucki Wydawnictwo Naukowe, Poznań.

PliŪRAité V., Kesminas V. 2004. Species composition of macroinvertebrates in medium-sized Lithuanian rivers. Acta Zoologica Lituanica 14: 10-25. https://doi.org/ 10.1080/13921657.2004.10512586

Pratt J. M., Coler R. A., Godfrey P. J. 1981. Ecological effects of urban stormwater runoff on benthic macroinvertebrates inhabiting the Green River, Massachusetts. Hydrobiologia 83: 29-42. https://doi.org/10.1007/ BF02187149

PROGRAM 2012. Program ochrony środowiska województwa lubelskiego na lata 2012-2015 z perspektywą do 2019 roku. Sejmik Województwa Lubelskiego, Lublin.

REPORT 2015. Raport o jakości wód rzeki Bug i jej dopływów w latach 2005-2014. Wojewódzki Inspektorat Ochrony Środowiska, Lublin.

REPORT 2016. Raport o stanie środowiska województwa lubelskiego w latach 2013-2015. Wojewódzki Inspektorat Ochrony Środowiska, Lublin.

REPORT 2017. Raport o stanie środowiska województwa lubelskiego w 2017 roku. Wojewódzki Inspektorat Ochrony Środowiska, Lublin.

Roy A. H., Rosemond A. D., Paul M. J., Leigh D. S., WALLACE J. B. 2003. Stream macroinvertebrate response to catchment urbanization (Georgia, U.S.A.). Freshwater Biology 48: 329-346. https://doi. org/10.1046/j.1365-2427.2003.00979.x

STEPENUCK, K. F., CRUNKILTON R. L., WANG L. 2002. Impacts of urban land use on macroinvertebrate communities in southeastern Wisconsin streams. Journal of the Americen Water Resources Association 38: 1041-1051. https://doi.org/10.1111/j.1752-1688.2002. tb05544.X

STRATEGY 2015. Strategia rozwoju miasta Międzyrzec Podlaski na lata 2015-2020 (z perspektywą do 2025 roku). Międzyrzec Podlaski.

ThORnE R. S. J., Williams W. P., GORdON C. 2000. The macroinvertebrates of a polluted stream in Ghana. Journal of Freshwater Ecology 15: 209-217. https://doi. org/10.1080/02705060.2000.9663738

Walsh C. J., Roy A. H., Feminella J. W., Cottingham P. D., Groffman P. M., Morgan R. P. 2005. The urban stream syndrome: current knowledge and the search for a cure. Journal of the North American Benthological Society 24: 706-723. https://doi.org/10.1899/04-028.1

WAlsh C. J., Sharpe A., BreEn P. F., SONNEMAN J. A. 2001. Effects of urbanization on streams of the Melbourne region, Victoria, Australia. I. Benthic macroinvertebrate 
communities. Freshwater Biology 46: 535-551. https:// doi.org/10.1046/j.1365-2427.2001.00690.x

WENGER S. J., ROY A. H., JACKSON C. R., BERNHARDT E. S., CARTER T. L., Fiolso S., GibSON C. A., Hession W. C., Kaushal S. S., Marti E., Meyer J. L., Palmer M. A., Paul M. J., Purcell A. H., Ramirez A., Rosemond A. D., SCHOField K. A., Sudduth E. B., WALSh C. J. 2009. Twenty-six key research questions in urban stream ecology: an assessment of the state of the science. Journal of the North American Benthological Society 28: 1080-1098. https://doi.org/10.1899/08-186.1

WŁosIK-BIEŃCZAK E. 1997. Mięczaki (Mollusca) rzeki Cybiny i sztucznych zbiorników wodnych utworzonych w jej biegu w granicach miasta Poznania w latach 19921994. Badania Fizjograficzne nad Polską Zachodnią, Seria C - Zoologia 44: 19-40.
WŁOSIK-BIEŃCZAK E. 2000. Fauna mięczaków (Mollusca) Strumienia Junikowskiego w Poznaniu w latach 19961999. Badania Fizjograficzne nad Polską Zachodnią, Seria C - Zoologia 47: 15-27.

WŁOSIK-BIEŃCZAK E. 2001. Malakofauna rzeki Bogdanki w Poznaniu w latach 1994-1998. Malacofauna of the River Bogdanka in Poznań in 1994-1998. Badania Fizjograficzne nad Polską Zachodnią, Seria C - Zoologia 48: 7-19.

Received: August 28th, 2018

Revised: October 19th, 2018

Accepted: October 27th, 2018

Published on-line: December 11th, 2018 